\title{
Comparative developmental biology of populations of three European and one North American Eubazus spp. (Hymenoptera: Braconidae), parasitoids of Pissodes spp. weevils (Coleoptera: Curculionidae)
}

\author{
M. Kenis \\ International Institute of Biological Control, European Station, Delémont, \\ Switzerland \\ M.A. Hulme \\ Canadian Forest Service, Pacific Forestry Centre, Victoria, Canada \\ N.J. Mills \\ Division of Biological Control, University of California, Berkeley, USA
}

\begin{abstract}
Observations were made on the developmental responses of the North American braconid species, Eubazus crassigaster, a parasitoid of the white pine weevil, Pissoles strobi, and three European congeneric species, E. semirugosus, $E$. robustus, and Eubazus sp. Several populations of Eubazus spp. were compared in their phenology in the laboratory and under natural conditions. When reared in the laboratory on non-diapausing Pissodes castaneus, mountain populations of $E$. semirugosus and $E$. robustus entered into an obligatory diapause in the host larva, whereas all the other populations tested developed continuously. Diapausing larvae continued their development only after having experienced at least three months at $2^{\circ} \mathrm{C}$. Non-diapausing populations of Eubazus spp. significantly differed in the duration of pre-imaginal development, with $E$. semirugosus being the fastest developing species and E. robustus the slowest. Outdoor rearings of Eubazus spp. on P. castaneus showed that E. crassigaster, Eubazus sp. and the lowland biotype of E. semirugosus emerged in the year of oviposition if this occurred early enough to allow parasitoid development. In contrast, a majority of $E$. robustus individuals overwintered in the host larvae, regardless of the oviposition date. The diapausing, mountain biotype of $E$. semirugosus is considered as the most promising candidate for control of $P$. strobi in Canada, because it is likely to be better adapted to the life cycle of the target host than the other Eubazus spp., including the native $E$. crassigaster.
\end{abstract}

\section{Introduction}

Correspondence: M. Kenis, IIBC European Station, I Chemin des Grillons, 2800 Delémont, Switzerland.
The white pine weevil, Pissodes strobi (Peck) ( $=P$. sitchensis Hopkins, P. engelmanni Hopkins) (Coleoptera: 
Curculionidae), is an important native forest pest in North America (Furniss \& Carolin, 1977; Drooz, 1985). Larvae feed in the inner bark of pine (Pinus spp.) and spruce (Picea spp.) (Pinaceae) leaders. The killed leader is replaced by laterals, which causes distorted growth and reduces timber quality (Silver, 1968; Alfaro, 1982; McMullen et al., 1987; Lavallée \& Benoit, 1989). In British Columbia, damage on Sitka spruce (Picea sitchensis) is so severe that new plantations of this highly valuable species have been suspended (Hall, 1994).

Current control methods are not effective, with the possible exception of clipping infested leaders (Lavallée \& Morissette, 1989). Among the native natural enemies, only the predator Lonchaea corticis Taylor (Diptera: Lonchaeidae) has a noticeable effect on Pissodes strobi populations, whereas parasitoids are of minor importance (e.g. Silver, 1968; VanderSar, 1978; Alfaro et al., 1985). Therefore, the Canadian Forest Service and the International Institute of Biological Control (IIBC) decided to initiate a biological control programme using parasitoids from congeneric European hosts. In a previous paper, Kenis \& Mills (1994) surveyed the parasitoid complex of five European Pissodes spp. and considered braconids of the genus Eubazus as the dominant parasitoids of all these Pissodes spp. and the most promising agents for the control of $P$. strobi in Canada. The taxonomy of this genus is still unclear. It was first thought that a single Eubazus species parasitized all European Pissodes spp. (e.g. Roques, 1975; Alauzet, 1987; Mills \& Fischer, 1986) but ecological, morphological and physiological observations (Kenis \& Mills, unpublished data) suggest that three distinct species exist, with separate microhabitat affinities (Kenis \& Mills, 1994): E. semirugosus (Nees) (=E. atricomis (Ratzeburg)) is a parasitoid of $P$. castaneus De Geer $(=P$. notatus (Fabricius)), $P$. pini (Linnaeus) and $P$. piniphilus (Herbst) in pine trunks, E. robustus (Ratzeburg) attacks $P$. validirostris (Sahlberg) in pine cones and an undescribed species parasitizes P. piceae (Illiger) in fir (Abies spp.) (Pinaceae) trunks. Eubazus semirugosus is also reported by Lovaszy (1941) as a parasitoid of $P$. harcyniae (Herbst), but, because of the confusion in Eubazus taxonomy, this record needs confirmation. In North America, Eubazus (=Allodorus) crassigaster (Provancher) is a parasitoid of P. strobi, P. dubius Randall, $P$. fasciatus LeConte, and P. terminalis Hopping (Deyrup, 1975; Marsh, 1979; Alfaro et al., 1985). Its impact on P. strobi populations is low and its distribution on this host is restricted to western coastal areas of North America (Silver, 1968; Alfaro et al., 1985).

All Eubazus spp. are egg-prepupal endoparasitoids, as defined by Mills (1994). Females oviposit in Pissodes spp. eggs. Eggs hatch soon after oviposition but the first instar larva delays its development until the host has reached the prepupal stage; then it grows quickly and emerges to complete its development externally (Haeselbarth, 1962; Annila, 1975; Roques, 1975; Alauzet, 1987).

In a biological control programme involving the introduction of an exotic natural enemy, it is essential to ensure synchronization between the phenology of the agent and that of the target host (e.g. Hoy, 1985; Cock, 1986; Stiling, 1993). This requirement becomes critical when the target host is a native species and the agent an exotic natural enemy collected from a related host, as the old and new hosts do not necessarily have the same phenology. Thus populations from the three European and one North American Eubazus spp. were compared in their phenology to allow selection of a European parasitoid population better adapted to $P$. strobi than the native $E$. crassigaster, which predominantly emerges in late summer whereas $P$. strobi oviposits in spring (Hulme, 1994). Preliminary observations, restricted to $E$. semirugosus, have already shown important intra-specific variation in the diapause requirement of this species (Kenis, 1994). Here we present the final results of our observations on the comparative developmental biology of different populations of the three European Eubazus spp. and the North American E. crassigaster.

\section{Material and methods}

\section{Collection and rearing of hosts and parasitoids}

Pissodes spp. and Eubazus spp. were obtained by collection of mature host larvae as described by Kenis \& Mills (1994) and Hulme (1994). Eubazus semirugosus was obtained from field collected pine logs containing $P$. castaneus, $P$. pini and $P$. piniphilus; E. robustus was reared from $P$. validirostris in pine cones and Eubazus sp. from fir logs containing $P$. piceae. Eubazus crassigaster was reared from Sitka spruce leaders attacked by P. strobi in Canada and shipped in the adult stage to Switzerland. Some pine cones were shipped from Europe to Canada and the adult E. robustus obtained in quarantine. Collection sites and dates are described in table 1. All Eubazus spp. adults used in our experiments had emerged directly from field collected material after having overwintered as larvae.

Eubazus spp. adults were reared in gauze covered wooden cages $50 \times 30 \times 30 \mathrm{~cm}$, at $21 \pm 2^{\circ} \mathrm{C}, \mathrm{L}: \mathrm{D} 16: 8$ and $70 \pm 10 \%$ relative humidity. They were fed with honey, and water was provided on moistened cellulose paper. Pissodes castaneus, $P$. pini and $P$. piniphilus were reared continuously in gauze covered wooden cages $(100 \times 50 \times 50 \mathrm{~cm})$ in the laboratory at $23 \pm 0.5^{\circ} \mathrm{C}, \mathrm{L}: \mathrm{D} 16: 8$ and $70 \pm 10 \%$ relative humidity. Fresh Scots pine (Pinus sylvestris) branches, partly immersed in water, were given as a food source for the adult weevils and renewed every fourth day. Freshly cut Scots pine logs $(4-10 \mathrm{~cm}$ diameter, $20-40 \mathrm{~cm}$ length) were sealed at the end with paraffin and offered to mature weevils for oviposition. At $23^{\circ} \mathrm{C}, P$. castaneus and $P$. pini have a pre-oviposition period of about three weeks, whereas $P$. piniphilus starts to oviposit after seven weeks (M. Kenis, unpublished data).

\section{Development at constant temperature}

Populations of Eubazus spp. from various hosts and sites were compared in their pre-imaginal development by rearing them in the laboratory on either $P$. castaneus or $P$. strobi under standard conditions. For rearings on $P$. castaneus, Scots pine logs were first offered to $P$. castaneus adults for oviposition for 4 days before being exposed for 2 days to 2- to 10-day-old Eubazus spp. females. Rearings on P. strobi were similar except the oviposition substrate was cut Sitka spruce leaders with the ends immersed in water. Then, the logs or leaders were kept in cages at $23 \pm 0.5^{\circ} \mathrm{C}, \mathrm{L}: \mathrm{D} 16: 8$ and $70 \pm 10 \%$ r.h. Emergence of both hosts and parasitoids was monitored daily to determine development time from oviposition to adult emergence. Four months after parasitoid oviposition, the logs or leaders were de-barked and the remaining host larvae were dissected to determine the percentage of Eubazus spp. remaining in diapause as larvae within their host. 


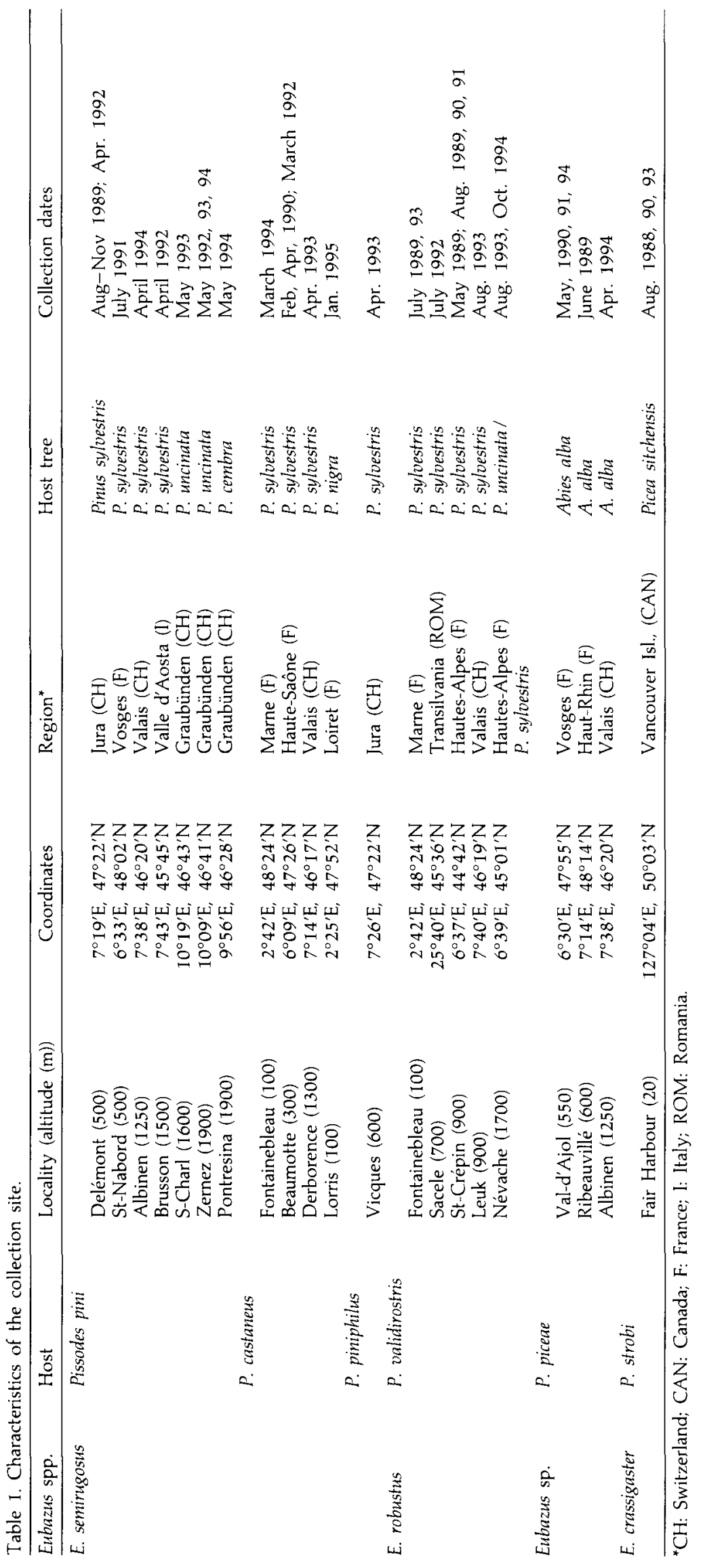


Four non-diapausing populations of Eubazus spp. from $P$. castaneus, $P$. piceae, $P$. validirostris and $P$. strobi were reared for a second generation on $P$. castaneus to observe whether differences in the development times are maintained after laboratory rearing on a standard host.

Six Eubazus spp. populations from P. castaneus, P. pini, P. piceae and $P$. validirostris were reared on $P$. pini and one from $P$. castaneus on $P$. piniphilus and the development times observed on these hosts were compared to those observed on $P$. castaneus.

In almost all experiments, sexes differed in their development time. Therefore, comparisons of development times between Eubazus spp. populations were made for each sex separately. When sample sizes were small, only males were used, as these usually emerged in higher numbers.

Percentages of Eubazus spp. in diapause were compared pairwise using the two-tail Fisher exact test. A two-tail t-test was used to compare differences in the duration of development between sexes. As variances in development times were not homogeneous between populations, even after logarithmic transformation, populations were compared in their development time using the Kruskal-Wallis test. Pairwise two-tail Mann-Whitney tests were used as a guide to which populations differ in development times.

\section{Diapause in E. semirugosus at higher altitudes}

A diapausing population of E. semirugosus from P. pini collected at high altitude $(1900 \mathrm{~m})$ at Zernez, in the Swiss Alps, was studied in more detail to determine, firstly, whether storage at low temperature breaks diapause, and secondly, whether the diapause is genetically fixed and maintained after rearing for one generation in the laboratory. This E. semirugosus population was reared on $P$. castaneus as described above and parasitoid emergence was monitored daily. Two months after parasitoid oviposition, when emergence of all the non-diapausing individuals was completed, the logs were put in cold storage at $2 \pm 1^{\circ} \mathrm{C}$ for 1, 2, 3 and 4 months. Following cold storage, the logs were incubated at $23 \pm 0.5^{\circ} \mathrm{C}$ to monitor parasitoid emergence. One month after incubation, the logs were de-barked and the host larvae remaining in diapause were dissected for parasitism. Eubazus semirugosus adults that emerged either before or after cold storage were reared for a second generation at $23^{\circ} \mathrm{C}$ on $P$. castaneus to determine the rate of diapausing parasitoids in this second generation.

\section{Development under natural conditions}

Populations of Eubazus spp. from P. castaneus, P. pini, $P$. validirostris, $P$. piceae and $P$. strobi were reared outdoors at the IIBC station in Delémont, Switzerland, from 1990 to 1993 , on $P$. castaneus to compare their pre-imaginal development under natural conditions. After having been exposed for four days to $P$. castaneus, individual logs were presented for 2 days to a particular Eubazus sp. population for oviposition in the laboratory. Pine logs were placed singly in outdoor cages under a plastic tunnel, protected from rain and direct sun, but exposed to natural temperature conditions. When possible, ovipositions were repeated at 1 or 2 week intervals from May to July inclusive. Host and parasitoid emergence was monitored daily. Logs were de-barked in October and the remaining host larvae dissected for parasitism. To determine whether parasitoids overwintering in the logs were in diapause or simply quiescent, some logs with overwintering parasitized host larvae were not de-barked but incubated at $23^{\circ} \mathrm{C}$ for parasitoid emergence. Two months after incubation, the logs were examined to count insects in diapause.

\section{Results}

\section{Eubazus spp. development at constant temperature}

Table 2 shows, for all Eubazus spp. populations reared in the laboratory on $P$. castaneus, the percentage of parasitoid larvae found in diapause in host larvae four months after oviposition. All three European Eubazus spp., when collected in the lowlands $(900 \mathrm{~m}$ or lower), developed without diapause, as did the North American E. crassigaster from $P$. strobi. In contrast, most of the Eubazus spp. populations reared from $P$. pini, $P$. castaneus and $P$. validirostris collected at higher altitudes (1250 m or higher) did not complete their development on the rearing host. The majority of the parasitoids were found as second instar larvae in living Pissodes spp. larvae four months after oviposition when all the unparasitized hosts had already emerged. In the two sympatric populations collected at Albinen $(1250 \mathrm{~m}), 90 \%$ of the progeny of Eubazus sp. from P. piceae emerged in the laboratory while the offspring of E. semirugosus from $P$. pini remained in diapause.

Most populations showed a consistent male biased sex ratio. As sex ratios in field populations varied little from 1 : I (M. Kenis, unpublished data), the bias toward males in laboratory rearing was probably related to rearing constraints such as lack of mating or overcrowding, though other factors such as high temperatures and overmating could not be excluded (Waage et al., 1985). Sexes differed significantly in the duration of development (table 2), with males usually emerging before females.

Significant differences were found between non-diapausing populations in the duration of development from oviposition to adult emergence at $23^{\circ} \mathrm{C}$ on $P$. castaneus (Kruskal-Wallis test: males: $H=332.85$, d.f. $=16, P<0.001$; females: $H=219.39$, d.f. $=15, P<0.001$ ). Eubazus semirugosus populations from the three pine trunk Pissodes spp. had a development time which was significantly shorter than that of all other Eubazus spp. The few individuals from the higher altitude, diapausing populations of E. semirugosus that emerged without diapause showed similar development times to those individuals from the low altitude, nondiapausing populations.

Eubazus robustus from $P$. validirostris in pine cones tended to have a longer development time than the other parasitoid species, but the population collected at St-Crépin developed faster than the other two populations of the same species. The difference between the development times of the two sympatric populations of E. semirugosus and E. robustus from Fontainebleau was highly significant (Mann-Whitney test for males: $z=8.22, P<0.001$ ), although the development of the E. semirugosus population from Fontainebleau was significantly slower than those of all other $E$. semirugosus populations. Intraspecific variation was also found in Eubazus sp. from P. piceae whose population collected at Albinen developed significantly slower than those from the two other sites.

Eubazus robustus and E. crassigaster were also reared successfully on P. strobi (table 3 ) in spruce leaders. No 


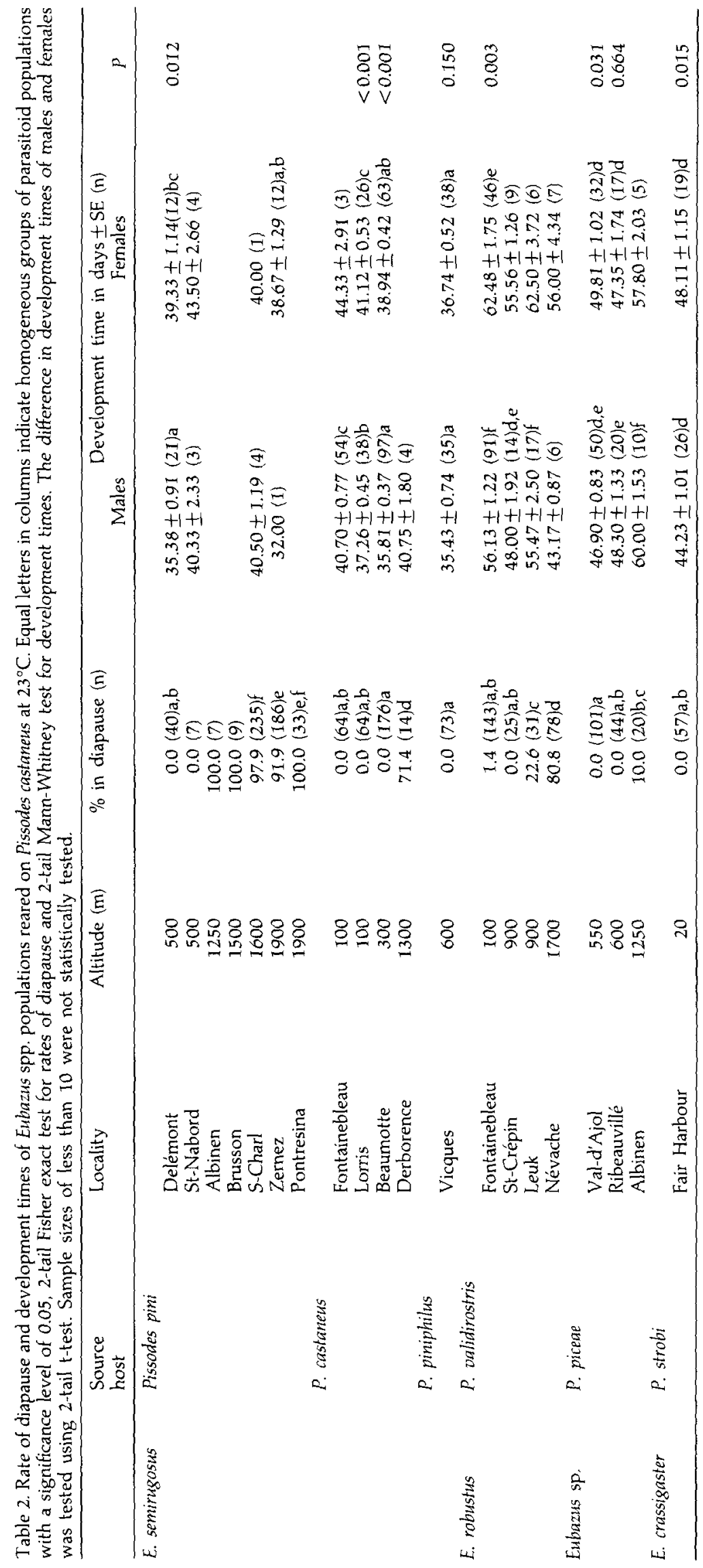


Table 3. Development times of males and females of Eubazus robustus from Fontainebleau and E. crassigaster from Fair Harbour reared on Pissodes strobi at $23^{\circ} \mathrm{C}$. Differences between sexes tested by 2-tail t-test. Equal letters in columns indicate homogeneous groups at 0.05 significance level, 2-tail Mann-Whitney test.

\begin{tabular}{lccr}
\hline \multicolumn{4}{c}{ Development time in days \pm SE (n) } \\
Males & Females & \multicolumn{1}{c}{$P$} \\
\hline E. robustus & $40.38 \pm 0.48(164) \mathrm{a}$ & $42.86 \pm 1.27(22) \mathrm{a}$ & 0.073 \\
E. crassigaster & $34.71 \pm 0.29(148) \mathrm{b}$ & $37.38 \pm 0.41(69) \mathrm{b}$ & $<0.001$ \\
\hline
\end{tabular}

diapause was observed for either of these two species on this host. As on P. castaneus, E. crassigaster developed faster than $E$. robustus, and males emerged before females.

The duration of development of males of the second generation of each parasitoid species reared in the laboratory is shown in table 4 . The differences between Eubazus species were maintained in the second generation, with $E$. semirugosus having the fastest development and $E$. robustus the slowest. For all populations, the second generation developed more slowly than the first. The difference between the two generations was slightly significant for $E$. robustus (Mann-Whitney test: $z=2.17, P=0.031$ ) and $E$. semirugosus $(z=1.98, P=0.049)$.

Males of the six Eubazus spp. populations reared on $P$. pini developed as fast on this host as on P. castaneus (table 5), although the pre-imaginal development of the two weevil species under laboratory conditions was significantly different: 78.26 days $(\mathrm{SE}=0.85, \mathrm{n}=104)$ for $P$. pini and 65.32 $(\mathrm{SE}=0.29, \mathrm{n}=595)$ for $P$. castaneus (t-test: $t=16,58$, d.f. $=697$, $P<0.001$ ). In contrast, the development time of the $E$. semirugosus population reared on $P$. piniphilus was longer than on the two other hosts. Pissodes piniphilus had a pre-imaginal development of 88.63 days $(\mathrm{SE}=1.73, \mathrm{n}=27$ ), which is significantly longer than that of $P$. pini (t-test: $t=5.45$, d.f. $=129, P<0.001$ ).

\section{Diapause in E. semirugosus at higher altitudes}

Most of the diapausing E. semirugosus emerged within 3 weeks following cold storage for 3 and 4 months at $2^{\circ} \mathrm{C}$ (fig. 1). In contrast, the majority of those which were kept only 2 months and all those kept 1 month in cold storage remained in diapause.

A fixed diapause was maintained after one generation of laboratory rearing in this high altitude population of $E$. semirugosus. Ninety-four per cent $(n=64)$ of the offspring of the diapausing parents, which had needed a cold treatment to emerge during the first generation, were also in diapause in the second generation. The few $E$. semirugosus which emerged without diapause in the first generation, when reared for a second generation produced three individuals that emerged while eight remained in diapause.

\section{Development under natural conditions}

Figures 2 and 3 show, for different Eubazus spp. populations, the emergence rate of each population reared during May, June and July under natural conditions on $P$. castaneus. It is unfortunate that not all the populations could be tested in the same year, which would have allowed a better comparison between populations. However, the development of the host can be taken as a reference as this was rather similar each year. When oviposition of $P$. castaneus occurred before mid-July (late-June in 1993), most of the weevils emerged in the same year while, when eggs were laid later, the larvae had insufficient time to complete their development and consequently, $P$. castaneus overwintered in the larval stage in the logs. Eubazus semirugosus from $P$. castaneus, Eubazus sp. from P. piceae and E. crassigaster from P. strobi showed a similar phenology. Early oviposition gave rise to adult emergence in the same year, but when eggs were laid in late-July, the parasitoid larvae could not complete their development in their host before winter and overwintered in host larvae. Eubazus semirugosus was able to complete its development even when the host could not. When the overwintering hosts parasitized by E. crassigaster, Eubazus sp., and the lowland population of E. semirugosus were incubated in the laboratory in autumn, all the parasitoids emerged.

The development pattern of $E$. robustus under natural conditions was different from that of other parasitoid species

Table 4. Development time of males of first and second generations of Eubazus species from non-diapausing populations reared on Pissodes castaneus at $23^{\circ} \mathrm{C}$. Equal letters in column indicate homogeneous group at 0.05 significance level, 2-tail Mann-Whitney test.

\begin{tabular}{lll}
\hline & Host of origin (collection site) & Development time in days $\pm \mathrm{SE}(\mathrm{n})$ \\
\hline E. semirugosus & P. castaneus (Beaumotte) & \\
& 1st gen. & $35.81 \pm 0.37(97) \mathrm{a}$ \\
& 2nd gen. & $37.59 \pm 1.11(34) \mathrm{b}$ \\
E. robustus & P. validirostris (St-Crépin) & \\
& 1st gen. & $48.00 \pm 1.92(14) \mathrm{c}$ \\
& 2nd gen. & $53.86 \pm 1.44(14) \mathrm{d}$ \\
Eubazus sp. & P. piceae (Val-d'Ajol) & $46.90 \pm 0.83(50) \mathrm{c}$ \\
& 1st gen. & $47.17 \pm 1.25(24) \mathrm{c}$ \\
2nd gen. & \\
E. crassigaster & P. strobi (Fair Harbour) & $44.23 \pm 1.01(26) \mathrm{c}$ \\
& 1st gen. & $47.40 \pm 1.01(10) \mathrm{c}$ \\
\hline
\end{tabular}


Table 5. Development time of males of European Eubazus species from non-diapausing populations reared at $23^{\circ} \mathrm{C}$ on Pissodes castaneus, $P$. pini and $P$. piniphilus. Equal letters in column indicate homogeneous groups at 0.05 significance level, 2-tail Mann-Whitney test.

\begin{tabular}{|c|c|c|c|}
\hline & Host of origin (collection site) & Rearing host & Development time in days \pm SE ( $n$ ) \\
\hline \multirow[t]{5}{*}{ E. semirugosus } & P. castaneus (Beaumotte) & P. castaneus & $35.81 \pm 0.37(97) a$ \\
\hline & & P. pini & $37.06 \pm 0.72(32) \mathrm{a}$ \\
\hline & & P. piniphilus & $45.85 \pm 0.79(13) \mathrm{b}$ \\
\hline & P. pini (Delémont) & P. castaneus & $35.38 \pm 0.91(21) a$ \\
\hline & & P. pini & $36.07 \pm 1.01(27) \mathrm{a}$ \\
\hline \multirow{4}{*}{ E. robustus } & P. validirostris (Fontainebleau) & P. castaneus & $56.13 \pm 1.22(91) \mathrm{d}$ \\
\hline & & P. pini & $58.67 \pm 4.35(24) \mathrm{c}, \mathrm{d}$ \\
\hline & P. validirostris (St-Crépin) & P. castaneus & $48.00 \pm 1.92(14) \mathrm{b}, \mathrm{c}$ \\
\hline & & P. pini & $52.81 \pm 2.16(21) \mathrm{c}, \mathrm{d}$ \\
\hline \multirow[t]{4}{*}{ Eubazus sp. } & P. piceae (Ribeauvillé) & P. castaneus & $48.30 \pm 1.33(20) b, c$ \\
\hline & & P. pini & $52.57 \pm 2.76(7) \mathrm{c}, \mathrm{d}$ \\
\hline & P. piceae (Val-d'Ajol) & P. castaneus & $46.90 \pm 0.83(50) b$ \\
\hline & & P. pini & $49.67 \pm 1.50(12) b, c, d$ \\
\hline
\end{tabular}

(fig. 3). All the E. robustus populations tested had an important proportion of individuals that stayed in the logs for overwintering in the larval stage, even when the unparasitized hosts emerged. In contrast to the other Eubazus species, the proportion of overwintering individuals was not related to the date of oviposition. This proportion was higher in populations from higher altitude sites (e.g. St-Crépin and Leuk) than from the lower altitude site (Fontainebleau). Forty five per cent $(n=31)$ of the parasitoids did not emerge when they were incubated in autumn but stayed in their host in a true diapause, whereas all $(n=83)$ unparasitized hosts emerged on incubation in autumn.

The high altitude ecotype of $E$. semirugosus from $P$. pini, collected at Zernez, was also reared on $P$. castaneus under natural conditions. As observed in the laboratory, all remained in diapause within their hosts, regardless of the oviposition date. In addition, none of them emerged when parasitized hosts within logs were incubated in autumn, the diapause being confirmed by subsequent de-barking.

\section{Discussion}

\section{Variations in developmental responses}

Parasitoids often show important variation between strains. Ruberson et al. (1989) and Hopper et al. (1993) list examples of intraspecific variation in traits which are likely to affect the establishment of a parasitoid in a biological control programme. Among these, variability in developmental responses (including development rate, diapause,

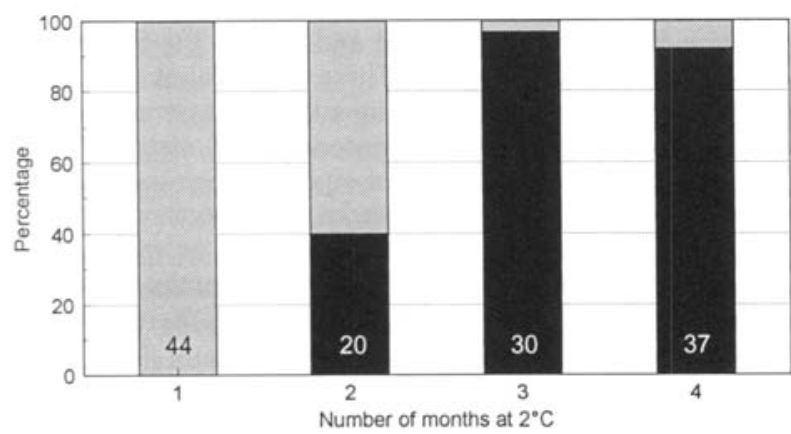

Fig. 1. Percentages of diapausing Eubazus semirugosus emerging (solid bars) or remaining in diapause (hatched bars) after 1, 2, 3 and 4 months at $2^{\circ} \mathrm{C}$. Numbers in the bars represent the sample size.
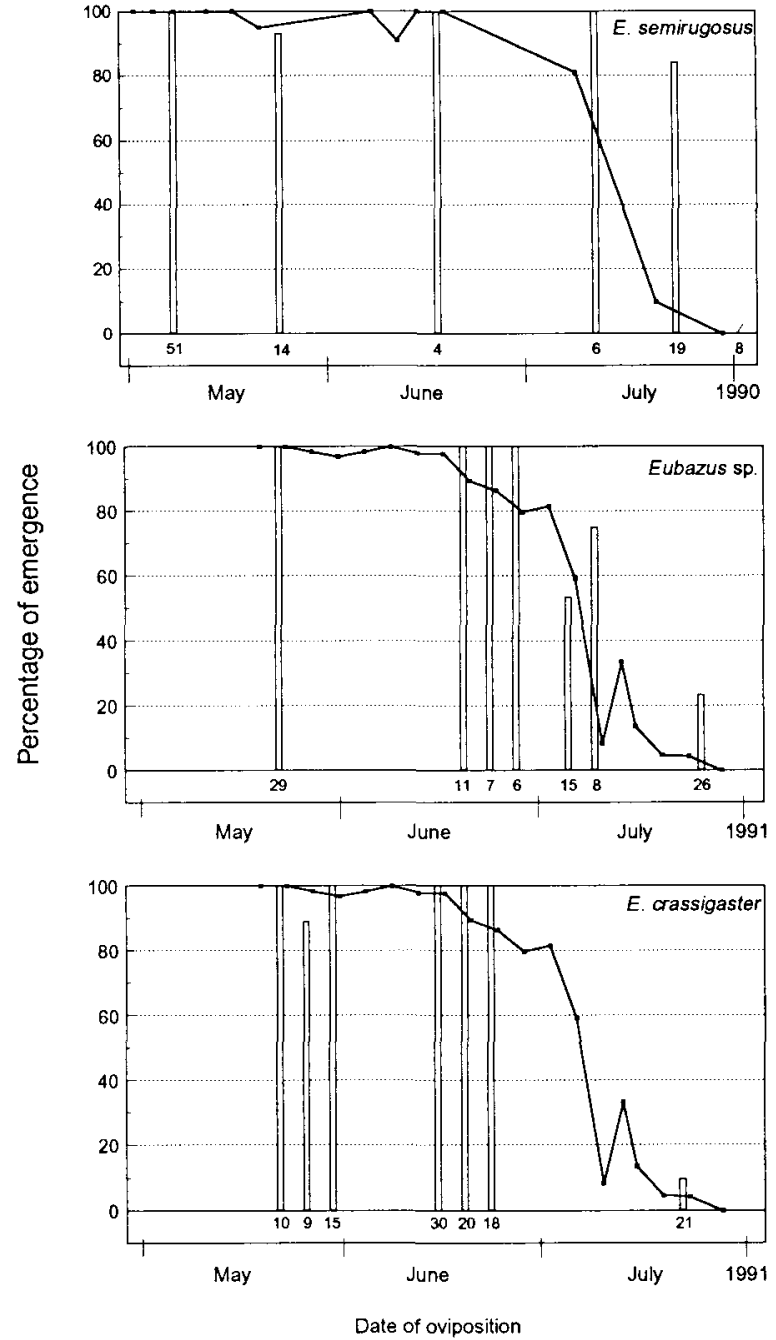

Fig. 2. Percentage of summer emergence of Pissodes castaneus (lines) and Eubazus semirugosus, Eubazus sp. and E. crassigaster (bars) reared outdoors on P. castaneus in relation to oviposition dates. Eubazus semirugosus was reared from $P$. castaneus collected at Beaumotte, Eubazus sp. emerged from P. piceae, Val-d'Ajol and E. crassigaster from $P$. strobi, Fair Harbour. Numbers below the bars represent the total number of parasitoids reared. For $P$. castaneus, each point represents the mean of at least ten individuals. 

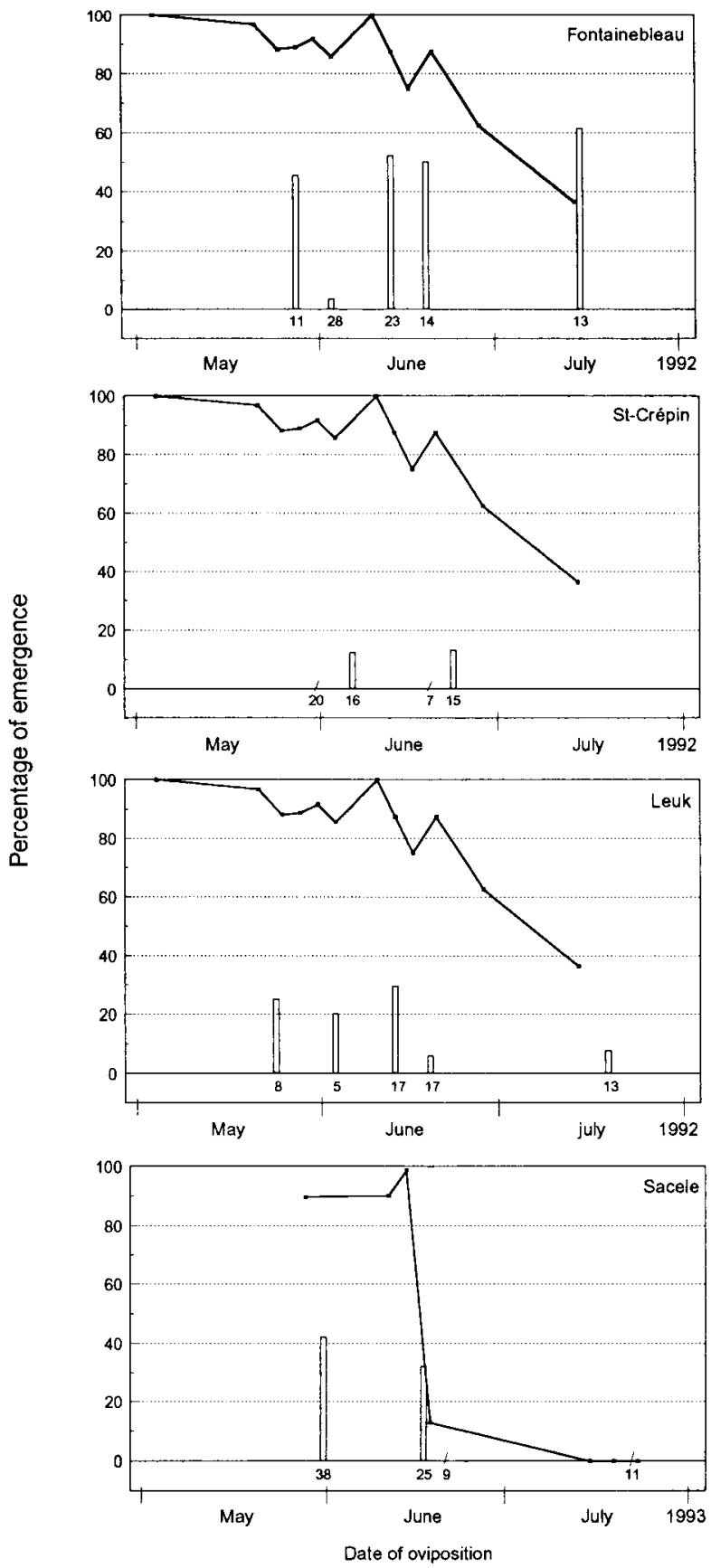

Fig. 3. Percentage of summer emergence of $P$. castaneus (lines) and four populations of $E$. robustus (bars) reared outdoors on P. castaneus in relation to oviposition dates. Numbers below the bars represent the total number of parasitoids reared. For $P$. castaneus, each point represents the mean of at least ten individuals.

survival in response to temperature, etc.) has been the most commonly reported difference. However, many of these variations may be due to the occurrence of undetected sibling species (e.g. Hafez \& Doutt, 1954; Haardt \& Höller, 1992).

Although the Eubazus spp. populations reared from European Pissodes spp. weevils have been separated into three sister species, their taxonomic status remains to be clarified and a revision of the Palaerctic Eubazus spp. by $C$. van Achterberg and M. Kenis is in preparation. Nevertheless, observations on development times under standard conditions clearly support this separation. Eubazus semirugosus from the three pine trunk Pissodes spp. have the shortest pre-imaginal development time, Eubazus sp. from P. piceae and the Nearctic E. crassigaster develop more slowly and $E$. robustus shows the longest development time. Statistical differences in development time between two sympatric populations of $E$. semirugosus and $E$. robustus in France strongly suggest that these are different species. The difference in development time between $E$. semirugosus and other parasitoid species is maintained when they are reared for a second generation in the laboratory.

Important differences were found within Eubazus species in terms of diapause requirements. Populations of $E$. semirugosus and $E$, robustus collected at high altitude have an obligatory diapause, or 'parapause' sensu Thiele (1973). Young parasitoid larvae block the development of their host in the late larval stage but continue their development only after having experienced at least three months at $2^{\circ} \mathrm{C}$. In these mountain populations, a small percentage of individuals develop without diapause but, as diapausing offspring were obtained from non-diapausing individuals, the existence of two sibling species, one diapausing and one not, can be ruled out. The re-appearance of diapause in a second generation in captivity also suggests that the diapause is most probably genetically fixed. Crosses are in progress between diapausing and non-diapausing populations of $E$. semirugosus to assess the genetic basis of these phenotypic variations.

Differences between Eubazus spp. populations were also found when they were reared at regular intervals in spring on $P$. castaneus under natural conditions. Eubazus crassigaster, Eubazus sp. from P. piceae and the lowland biotype of $E$. semirugosus emerge in the year of oviposition if this occurs early enough to allow completion of host development before winter. In contrast, in all E. robustus populations tested, the majority of the parasitoids arrest the development of the host to emerge in the following spring, no matter whether oviposition occurs in May, June or July. This development on $P$. castaneus is very similar to that on its natural host (Annila, 1975; Roques, 1975). Pissodes validiros tris oviposits in pine cones in May and June and emerges in late summer but only a small proportion of the E. robustus emerge at the same time as the weevils, the bulk of the parasitoids overwinter in host larvae to emerge the following spring. The extent of $E$. robustus overwintering in cones was about $75 \%$ in central France (Roques, 1975) and in southern Finland (Annila, 1975) and 71\% in the Swiss Alps (M. Kenis, unpublished data). These percentages are similar to those observed in our experiments on $P$. castaneus. Many of the $E$. robustus larvae overwintering in $P$. castaneus were in true diapause, as they did not emerge when incubated in the laboratory in October. Similarly, when cones containing parasitized $P$. validirostris were incubated in mid-August before summer emergence, only about $30 \%$ of the E. robustus emerged in the three following months (M. Kenis, unpublished data)

The ability of diapausing populations of E. semirugosus and $E$. robustus to block the development of non-diapausing hosts strongly suggests active manipulation of the host endocrine system. Such a phenomenon is common among endoparasitoids (Lawrence, 1986; Lawrence \& Lanzrein, 
1993), particularly in other egg-prepupal parasitoids of the families Braconidae, sub-family Cheloninae (Jones, 1985), and Encyrtidae (Strand et al., 1990). There are other examples of endoparasitoids which, like Eubazus spp. delay host development to ensure synchronization with their host (e.g. Thorpe, 1933; Carl, 1976). However, to our knowledge, Eubazus spp. provide the only example of a host-parasitoid interaction that is characterized by diapause when, in the absence of parasitism, the host completes its development without diapause.

\section{Evolutionary issues of host-parasitoid synchronization}

Developmental responses of Eubazus spp. and biotypes have probably evolved to allow synchronization with the phenology of their respective hosts. Two biotypes of $E$. semirugosus exist, one found at high altitudes and another in the lowlands, because, in these different environments, Pissodes spp. have different phenologies. At high altitudes, $P$. pini only oviposits during the warmest months of the year, from June to August (M. Kenis, unpublished data). If associated populations of E. semirugosus were to emerge before the winter they would not find any Pissodes spp. eggs to attack. Thus, high altitude populations of E. semirugosus larvae overwinter in their host until the following spring when the Pissodes spp. adults oviposit and, in order to ensure larval overwintering, the E. semirugosus populations have developed an obligatory diapause. In these cold areas, P. pini cannot complete its development in the same year and has to spend at least one winter as a larva. Consequently, mountain populations of $P$. pini also tend to have an obligatory diapause when reared in the laboratory (Kenis, 1994). In the lowlands, the development of $P$. pini, $P$. castaneus and $P$. piniphilus is faster, the oviposition period lasts much longer and generations overlap, so that every developmental stage can be found at any time of the year, with the exception of pupae in winter (Kudela, 1974; Alauzet, 1977). Hence, lowland populations of E. semirugosus have no diapause and adults continue to emerge until climatic conditions do not allow adult activity. The lowland biotype of $E$. semirugosus has a shorter development time than other non-diapausing Eubazus spp., perhaps to avoid competition with ectoparasitoids of mature Pissodes spp. larvae which are much more abundant in lowland populations of pine Pissodes spp. than in mountain populations or in other Pissodes spp. (Kenis \& Mills, 1994).

Eubazus robustus also postpones its emergence to the following spring to coincide with the oviposition period of P. validirostris (Annila, 1975; Roques, 1975). However, in this case, about a quarter of the population emerges in late summer when no host eggs are available. Although it is hard to believe that the summer generation dies without breeding, in which case $E$. robustus would probably quickly evolve to emerge entirely after overwintering, there is some uncertainty where alternative hosts are concerned. Annila (1975) and Roques (1975), who made extensive studies on $P$. validirostris and their parasitoids, suppose that summer emerging Eubazus spp. would attack other Pissodes spp. or even Scolytidae, such as Tomicus piniperda (Linnaeus) or Ips sexdentatus (Boerner). During our surveys of the parasitoid complexes of European Pissodes spp., we reared about a dozen individuals of $E$. robustus from $P$. castaneus. This low number, compared to the thousands of $E$. robustus and $E$. semirugosus reared from their main hosts (Kenis \& Mills,
1994; M. Kenis, unpublished data), suggests that, for $E$. robustus, $P$. castaneus is only an accidental host. Scolytids are sometimes recorded as hosts for Eubazus spp. (see Mills, 1983, for review) but these records have to be regarded as dubious. Pissodes spp. eggs are laid in feeding holes in the bark or in cone scales and it is very unlikely that Eubazus spp. are able to locate scolytid eggs in galleries under the bark. Other possible alternative hosts for $E$. robustus are other weevils, e.g. species of the genus Magdalis which have a similar biology to that of Pissodes.

Pissodes piceae and its Eubazus sp. oviposit in fir trunks from May to July inclusive (Haeselbarth, 1962). Haeselbarth observed that very few Eubazus spp. develop from egg to adult in the same summer while our observations showed that, when the Eubazus sp. is reared in a similar climatic region on $P$. castaneus, eggs laid in May and June give rise to adult emergence in the same year. The difference is probably related to the development rates of these two hosts. Pissodes piceae, having a much slower development than $P$. castaneus, does not allow Eubazus sp. to complete its development before winter. Furthermore, one would expect less intraspecific variation in developmental responses in this Eubazus species than in E. semirugosus and E. robustus because, in Europe, the climatic range of fir is much more restricted than that of pine and, consequently, the life cycle of $P$. piceae shows much less variation than those of the four pine Pissodes species.

The North American E. crassigaster is badly synchronized with the life cycle of $P$. strobi. Pissodes strobi has a similar phenology to $P$. validirostris (McMullen et al., 1987). Females oviposit in May and June exclusively. Adults of the new generation emerge from July to September and overwinter in the duff to oviposit in the following spring. Unlike $E$. robustus on $P$. validrostris, E. crassigaster is unable to block host development and, consequently, emerges before winter. The only regions where $E$. crassigaster is found on $P$. strobi are those where the summer is cold enough to slow the development of $P$. strobi to allow a small part of its population to overwinter as larva, in which case some $E$. crassigaster overwinter together with their host (Hulme, 1994). The question why E. crassigaster has not evolved to improve synchronization with $P$. strobi remains open. One possible explanation is that $P$. strobi is only an accidental host. Other host records for $E$. crassigaster include $P$. terminalis (Alfaro et al., 1985), P. fasciatus and P. dubius (Deyrup, 1975, 1978; Marsh, 1979). Pissodes terminalis and P. fasciatus overwinter partly as larvae (Stark \& Wood, 1964; Deyrup, 1978) and are theoretically more susceptible to parasitism by E. crassigaster. Indeed, Deyrup (1975) mentions $E$. crassigaster as very abundant on $P$. fasciatus.

\section{Implications for biological control}

To ensure the establishment of a Eubazus species on $P$. strobi, it is of crucial importance to select the species, biotype or strain which will be the best adapted to the phenology of the target host. From our observations on comparative development of European and American Eubazus spp., it appears that the diapausing biotypes of E. semirugosus and $E$. robustus are better adapted to the life cycle of $P$. strobi than are any other Eubazus spp., including the native E. crassigaster, because they are more likely to block the development of their host to overwinter in the host larva and emerge in spring during the oviposition period of $P$. strobi. 
Non-diapausing Eubazus spp. would most probably emerge during the summer, as $E$. crassigaster usually does, and would then be lost or would have to find an alternative host.

Eubazus robustus can attack and develop successfully on $P$. strobi in the laboratory and there is little doubt that high altitude E. semirugosus will also do so. Whether these two species will cause $P$. strobi larvae to enter diapause remains to be verified. As this diapause is obligatory in the mountain biotypes of E. semirugosus, it seems likely that it would occur also on the novel North American host. Eubazus robustus from high altitude sites apparently also has an obligatory diapause, but more populations should be tested before drawing firm conclusions. On the other hand, lowland populations of $E$. robustus cause partial host diapause 'only when reared outdoors. The factors inducing this diapause are not known and it is not clear whether this interaction would be repeated in North America on P. strobi. Another disadvantage of $E$. robustus, compared to $E$. semirugosus, is its specific microhabitat (pine cones) while E. semirugosus can be found in all parts of the trunk, including the leader. Therefore, we consider the mountain biotype of E. semirugosus as the best candidate for introduction against $P$. strobi.

Some problems, however, may still arise, which could impede parasitoid establishment. These problems are different in western and eastern North America. In western North America, P. strobi attacks spruces (McMullen et al., 1987), and it is not certain yet whether E. semirugosus or E. robustus, both pine-associated species in Europe, will naturally locate and attack $P$. strobi in spruce leaders. However, learning of host-finding cues is a well known phenomenon in insect parasitoids (e.g. Turlings et al., 1993). Hence, rearing the selected Eubazus species on P. strobi in the laboratory or in field cages prior to field releases would probably augment the chance of establishment. In eastern North America, both pines and spruces are attacked by $P$. strobi (Lavallée \& Benoit, 1989) and E. semirugosus would most certainly locate infested pine leaders easily. In this region, however, parasitized larvae might have difficulties in surviving cold winter temperatures. Hulme et al. (1986) have shown that $P$. strobi larvae in leaders hardly survive temperatures of $-20^{\circ} \mathrm{C}$ that are frequent in eastern North America. Nevertheless, these observations were made with the western North American biotype of $P$. strobi which was earlier thought to be a different species from the eastern North American biotype (Smith \& Sugden, 1969) and it is possible that the eastern biotype is more cold tolerant than the western. Furthermore, parasitism strongly influences host metabolism and physiology (Vinson \& Iwantsch, 1980; Beckage, 1993), which could also induce greater cold tolerance.

\section{Acknowledgements}

We thank the Canadian Forest Service for financial support, Alain Roques, Jean-Paul Raimbault and Vasile Mihalciuc for the collection of pine cones in France and Romania, and Marion Seier, Sabine Leroy, Kirsten Kock, Carlos Lopez-Vaamonde and Patrice Chalon for field and laboratory support. We also thank Klaus Carl and JeanClaude Grégoire for their comments on an earlier version of this manuscript and Kees van Achterberg for the identification of the Eubazus spp., voucher specimens of which are stored in the collections of the IIBC European Station, Delémont, Switzerland.

\section{References}

Alauzet, C. (1977) Cycle biologique de Pissodes notatus (Coleoptera Curculionidae) dans la région Toulousaine (France). Canadian Entomologist 109, 597-603.

Alauzet, C. (1987) Bioecologie de Eubazus semirugosus, Coeloides abdominalis et $C$. sordidator (Hym.: Braconidae) parasites de Pissodes notatus (Col.: Curculionidae) dans le sud de la France. Entomophaga 32, 39-47.

Alfaro, R.I. (1982) Fifty year-old Sitka spruce plantations with a history of intense weevil attack. Journal of the Entomological Society of British Columbia 79, 62-65.

Alfaro, R.I., Hulme, M.A. \& Harris, J.W.E. (1985) Insects associated with the Sitka spruce weevil, Pissodes strobi (Col.: Curculionidae) on Sitka spruce, Picea sitchensis in British Columbia, Canada. Entomophaga 30, 415-418.

Annila, E. (1975) The biology of Pissodes validirostris Gyll. (Col., Curculionidae) and its harmfulness, especially in Scots pine seed orchards. Communicationes Instituti Forestalis Fenniae 85 , $1-95$.

Beckage, N.E. (1993) Games parasites play: the dynamic roles of proteins and peptides in the relationship between parasite and host. pp. 25-57 in Beckage, N.E., Thompson, S.N. \& Frederici, B.A. (Eds) Parasites and pathogens of insects. Vol. 1. San Diego, Academic Press.

Carl, K.P. (1976) The natural enemies of the pear-slug, Caliroa cerasi (L.) (Hym., Tenthredinidae), in Europe. Zeitschrift für angewandte Entomologie 80, 138-161.

Cock, M.J.W. (1986) Requirements for biological control. Biocontrol News and Information 7, 7-16.

Deyrup, M.A. (1975) The insect community of dead and dying Douglas-fir. I. The Hymenoptera. Coniferous Forest Biome Bulletin 6, 1-104.

Deyrup, M.A. (1978) Notes on the biology of Pissodes fasciatus LeConte and its insect associates. Pan-Pacific Entomologist 54, $103-106$

Drooz, A.T. (1985) Insects of eastern forests. USDA Forest Service, Miscellaneous Publications 1426, 1-608.

Furniss, R.L. \& Carolin, U.M. (1977) Western forest insects. USDA Forest Service, Miscellaneous Publications 1339, $1-654$.

Haardt, H. \& Höller, C. (1992) Differences in life history traits between isofemale lines of the aphid parasitoid Aphelinus abdominalis (Hymenoptera: Aphelinidae). Bulletin of Entomological Research 82, 479-484.

Haeselbarth, E. (1962). Zur Biologie, Entwicklungsgeschichte und Oekologie von Brachistes atricornis Ratz. als eines Parasiter von Pissodes piceae. Zeitschrift für Angewandte Entomologie 49, 233-289.

Hafez, M. \& Doutt, R.L. (1954) Biological evidences of sibling species in Aphytis maculicornis (Masi). (Hymenoptera, Aphelinidae). Canadian Entomologist 86, 90-96.

Hall, P.M. (1994) Ministry of Forests perspectives on spruce reforestation in British Columbia. pp. 1-6 in Alfaro, R.I., Kiss, G. \& Fraser, R.G. (Eds) The white pine weevil biology, damage, and management. Forest Resource Development Agreement Report 226.

Hopper, K.R., Roush, R.T. \& Powell, W. (1993) Management of genetics of biological control introductions. Annual Review of Entomology 38, 27-51.

Hoy, M.A. (1985) Improving establishment of arthropod natural enemies. pp. 151-166 in Hoy, M.A. \& Herzog D.C. (Eds) Biological control in agricultural IPM systems. New York, Academic Press. 
Hulme, M.A. (1994) The potential of Allodorus crassigaster for the biological control of Pissodes strobi.pp. 294-300 in Alfaro, R.1., Kiss, G. \& Fraser, R.G. (Eds) The white pine weevil: biology, damage, and management. Forest Resource Development Agreement Report 226.

Hulme, M.A., Dawson, A.F. \& Harris, J.W.E. (1986) Exploiting cold-hardiness to separate Pissodes strobi (Peck) (Coleoptera: Curculionidae) from associated insects in leaders of Picea sitchensis (Bong.) Carr. Canadian Entomologist 118, 11151122.

Jones, D. (1985) Endocrine interaction between host (Lepidoptera) and parasite (Cheloninae: Hymenoptera): is the host or the parasite in control? Annals of the Entomological Society of America 78, 141-148

Kenis, M. (1994) Variations in diapause among populations of Eubazus semirugosus (Nees) (Hym.: Braconidae), a parasitoid of Pissodes spp. (Col.: Curculionidae). Norwegian Journal of Agricultural Sciences, Supplement 16, 77-82.

Kenis, M. \& Mills, N.J. (1994) Parasitoids of European species of the genus Pissodes (Col: Curculionidae) and their potential for the biological control of Pissodes strobi (Peck) in Canada. Biological Control 4, 14-21.

Kudela, M. (1974) Curculionidae, Pissodini. pp. 299-310 in Schwenke, W. (Ed) Die Forstschädlinge Europas. 2 Band. Hamburg, Paul Parey.

Lavallée, R. \& Benoit, P. (1989) Le charançon du pin blanc. Forêts Canada, Feuillet d'Information, CFL 18, 1-13.

Lavallée, R. \& Morissette, J. (1989) Le Conţrôle mécanique du charançon du pin blanc. Forêts Canada, Feuillet d'Information. CFL 25, 1-9.

Lawrence, P.O. (1986) Host-parasite hormonal interactions: an overview. Journal of Insect Physiology 32, 295-298.

Lawrence, P.O. \& Lanzrein, B. (1993) Hormonal interactions between insect endoparasitoids and their host insects. pp. 59 86 in Beckage, N.E., Thompson, S.N. \& Frederici, B.A. (Eds) Parasites and pathogens of insects. Vol. I. San Diego, Academic Press.

Lovaszy, P. (1941) Zur Kenntnis der Schlupwespen einiger schädlichen Rüsselkäfer. Annales Entomologica Fennici 7, 194-204.

McMullen, L.H., Thomson, A.J. \& Quenet, R.V. (1987) Sitka spruce weevil (Pissodes strobi) population dynamics and control: a simulation model based on field relationships. Canadian Forestry Service, Pacific Forestry Centre, Information Report BC-X-288, 1-20.

Marsh, P.M. (1979) Braconidae, pp. 144-295 in Krombein, K.V. et al. (Eds) Catalog of Hymenoptera in America North of Mexico 1. Washington, D.C.. Smithsonian Institution Press.

Mills, N.J. (1983) The natural enemies of scolytids infesting conifer bark in Europe in relation to the biological control of Dendroctonus spp. in Canada. Biocontrol News and Information 4, 305-328.

Mills, N.J. (1994) Parasitoid guilds: defining the structure of the parasitoid communities of endopterygote insect hosts. Environmental Entomology 23, 1066-1083.
Mills, N.J. \& Fischer, P. (1986) The entomophage complex of Pissodes weevils, with emphasis on the value of $P$. validirostris as a source of parasitoids for use in biological control. pp. 297-305 in Roques, A. (Ed.) Proceedings of the 2nd International Conference of the IUFRO Cone and Seed Insects Working Party, Briançon, Sept. 1986. Olivet (France), INRA.

Roques, A. (1975) Etude de la mérocénose des Cônes de pins sylvestres en forêt de Fontainebleau. $164 \mathrm{pp}$. Thèse 3e cycle, Paris VI.

Ruberson, J.R., Tauber, M.J. \& Tauber, C.A. (1989) Intraspecific variability in hymenopteran parasitoids: comparative studies of two biotypes of the egg parasitoid Edovum puttleri (Hymenoptera: Eulophidae). Journal of the Kansas Entomological Society 62, 189-202.

Silver, G.T. (1968) Studies on the Sitka spruce weevil, Pissodes sitchensis in British Columbia. Canadian Entomologist 100, 93-100.

Smith, S.G. \& Sudgen, B.A. (1969) Host trees and breeding sites of native North American Pissodes bark weevils, with a note on synonymy. Annals of the Entomological Society of America 62, 146-148

Stark, R.W. \& Wood, D.L. (1964) The biology of Pissodes terminalis Hopping (Coleoptera: Curculionidae) in California. Canadian Entomologist 96, 1208-1218.

Stiling, P. (1993) Why do natural enemies fail in classical biological control programs? American Entomologist 39, 3137.

Strand, M.R., Dover, B.A. \& Johnson, J.A. (1990) Alterations in the ecdysteroid and juvenile hormone esterase profiles of Trichoplusia ni parasitized by the polyembryonic wasp Copidosoma floridanum. Archives of Insect Biochemistry and Physiology 13, 41-51.

Thiele, H.U. (1973) Remarks about Mansingh's and Müller's classifications of dormancies in insects. Canadian Entomologist 105, 925-928.

Thorpe, W.H. (1933) Notes on the natural control of Coleophora laricella, the larch case bearer. Biology and morphology of Angitia nana. Bulletin of Entomological Research 24, 273-277.

Turlings, T.C.J., Wäckers, F.L., Vet, L.E.M., Lewis, W.J. \& Tumlinson, J.H. (1993) Learning of host-finding cues by hymenopterous parasitoids. pp. 51-78 in Lewis, A.C. \& Papaj, D.R. (Eds) Insects learning: ecological and evolutionary perspectives. New York, Chapman and Hall.

VanderSar, T.J.D. (1978) Emergence of predator and parasites of the white pine weevil, Pissodes strobi (Coleoptera: Curculionidae) from Engelmann spruce. Journal of the Entomological Society of British Columbia 75, 14-18.

Vinson, S.B. \& Iwantsch, G.F. (1980) Host regulation by insect parasitoids. Quarterly Review of Biology 55, 143-165.

Waage, J.K., Carl, K.P., Mills, N.J. \& Greathead, D.J. (1985) Rearing entomophagous insects. pp. 45-66 in Singh, P. \& Moore, R.F. (Eds) Handbook of insect rearing Vol. 1. Amsterdam, Elsevier

(Accepted 21 September 1995) C CAB INTERNATIONAL, 1996 